\title{
Changes in the composition of the land snail fauna of Mt. Ciampea, West Java, Indonesia
}

\author{
Ayu Savitri Nurinsiyah ${ }^{1,2 *}$ and Bernhard Hausdorf ${ }^{2}$ \\ ${ }^{1}$ Zoology Division, Research Center for Biology, Indonesian Institute of Sciences, Km.46, Jl. Raya Bogor, Cibinong, \\ West Java, 16911 Indonesia \\ ${ }^{2}$ Center of Natural History, Universität Hamburg, Martin-Luther-King-Platz 3, Hamburg, 20146 Germany
}

\begin{abstract}
Mt. Ciampea is a limestone outcrop surrounded by human settlements in West Java. To update the inventory of land snail species from Mt. Ciampea and to compare it with the previous records, we sampled land snails at eight plots $(10 \mathrm{~m} \times 10 \mathrm{~m})$ in January 2013 and May 2014. In total, 1702 specimens belonging to 16 families and 34 species were collected. Stomacosmethis jagori (Cyclophoridae) was the dominant species comprising $24 \%$ of the individuals. The number of species was similar to a previous survey, in which 38 species were recorded, but the species composition was different. Sixteen of the previously recorded species were not found in our survey, but we could record 13 species that were not known from Mt. Ciampea so far. Among them were two invasive species, Lissachatina fulica (Achatinidae) and Bradybaena similaris (Camaenidae) that colonized the area since the early 20th century. A more detailed survey will be necessary to ascertain whether and which previously recorded species are actually extinct on Mt. Ciampea.
\end{abstract}

\section{Introduction}

Indonesia has the most extensive limestone outcrops $\left(154.000 \mathrm{~km}^{2}\right)$ in South East Asia. Java, the most populated island in Indonesia, has $5500 \mathrm{~km}^{2}$ of limestone outcrops [1]. Limestone karsts are "arks" of biodiversity and often contain high levels of endemism [2]. This is particularly true for land snails which are abundant and species rich in karst areas because the calcium-rich soils favour their growth and reproduction [3,4]. Land snail endemism peaks on karsts because of the low dispersal abilities of land snails and the isolation of karst areas [5]. Low dispersal abilities and the requirement for undisturbed habitats make land snails vulnerable to extinction [6]. Limestone quarrying is the primary threat to karst biodiversity in Southeast Asia, where quarrying rates exceed those in other tropical regions and caused declines and extinctions among site-endemic taxa [2].

Many limestone outcrops in Java are located adjacent to or within urban areas and surrounded by human settlements. Mt. Ciampea is such a limestone hill near Ciampea village in West Java (Fig. 1). It is composed of long coral reefs from the Miocene that have been raised up to $350 \mathrm{~m}$ above sea level [7]. For years, the area has been suffering from ongoing quarrying and land use change towards agriculture and plantations. In the past years, some parts of the area also became a destination for hikers and campers. As a consequence, the area's biodiversity is declining. Two endemic plants, Zeuxine tjiampeana and Dipterocarpus hasseltii, could not be refound despite intensive research in the area [7]. Silvery Javan Gibbon (Hylobates moloch) used to inhabit Mt. Ciampea, but could also not be found anymore [8].

Leschke [9] was probably the first who surveyed land snails at Mt. Ciampea. He recorded five species from the mountain. Van Benthem Jutting [10] collected in 1930/1931 at Mt. Ciampea. She discovered and described two new Opisthostoma species, O. javanicum and $O$. uranoscopium from Mt. Ciampea. Whereas $O$. javanicum was later also recorded from other Indonesian islands, Madura, Bali, Borneo and Sulawesi, $O$. uranoscopium was only recently found in a few other localities in West Java and Banten [11]. Van Benthem Jutting [12-14] compiled the previous findings and listed 38 species of land snails from Mt. Ciampea.

In face of the threat to the fauna on Mt. Ciampea by quarrying, land use change and tourism, an updated record of the land snail fauna of the area is urgently needed. For this reason, we conducted a land snail survey on Mt. Ciampea and compared the recorded species with those listed in the literature.

\footnotetext{
* Corresponding author: ayus002@lipi.go.id; ayu nurinsiyah@yahoo.com
} 


\section{Material and Methods}

\subsection{Study Site}

Mt. Ciampea (also known as Mt. Cibodas) is located in Ciampea District, Bogor Regency, West Java, Indonesia $\left(06^{\circ} 33^{\prime} 05^{\prime \prime} \mathrm{S}\right.$ to $06^{\circ} 33^{\prime} 11^{\prime \prime} \mathrm{S}$ and $106^{\circ} 40^{\prime} 59^{\prime \prime} \mathrm{E}$ to $106^{\circ} 41^{\prime} 14$ 'E, Fig. 1, 2). It ranges from 285 to $357 \mathrm{~m}$ above sea level. The soil in Ciampea is alkaline to neutral $(\mathrm{pH} 6.5-7)$. Air temperature ranges from $27.7^{\circ} \mathrm{C}$ to $37.2{ }^{\circ} \mathrm{C}$ and humidity from $60.2 \%$ to $77.3 \%$ [7]. Most of the area on the upper part is covered by secondary forest and limestone rocks, whereas the lower part is used for agroforestry and teak plantation.

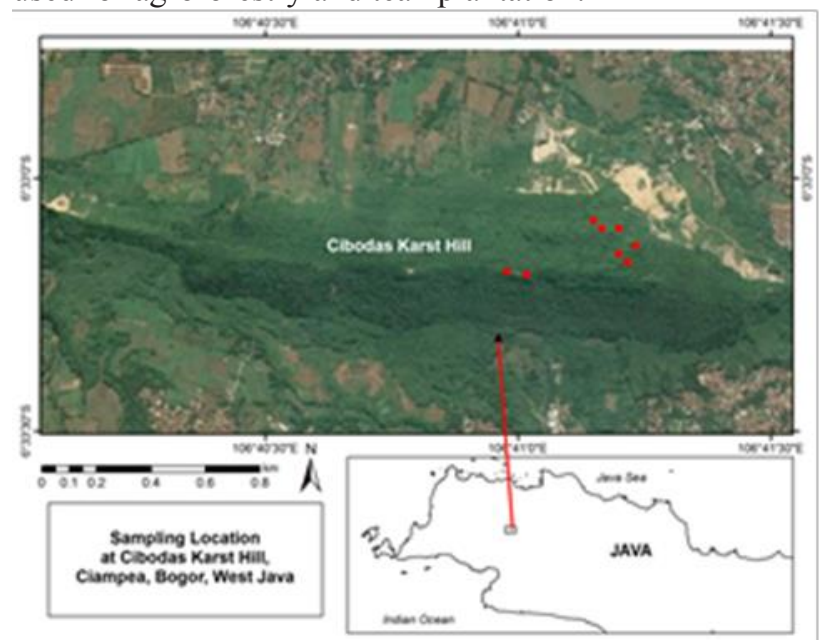

Fig. 1. Mt. Sampling location

\subsection{Sampling and Determination}

Samples were collected in January 2013 and May 2014. In total, eight plots of $10 \mathrm{~m} \times 10 \mathrm{~m}$ each were sampled. The plots were located within the outcrops near or at the mouth of caves, and on limestone rocks. We applied a combination of visual searching and sorting a standardized volume of litter and soil as recommended for land snail inventories if repeated visits are not possible [15-17]. All living slugs and snails as well as their empty shells were collected by the junior author for one hour at each plot. In addition, 5 litres of soil and leaf litter (3-5cm of topsoil) were collected at each plot. The soil and leaf litter samples were put into water and the floating plant material and snails were collected with a sieve. Afterwards, the material was dried and sieved to pick out the microsnails. The snails were sorted and identified to species level using van Benthem Jutting [12-14], Vermeulen [18], Nurinsiyah \& Hausdorf [11] and Nurinsiyah et al. [19].

\subsection{Statistical Analysis}

Every specimen was counted to reveal species richness and abundance. The similarity between past and present records was analysed using the Jaccard (absolute abundances) and Chao-Jaccard (relative abundances) indices with 100 bootstraps replicates with the TwoCommunity Measures as implemented in SpadeR [20].
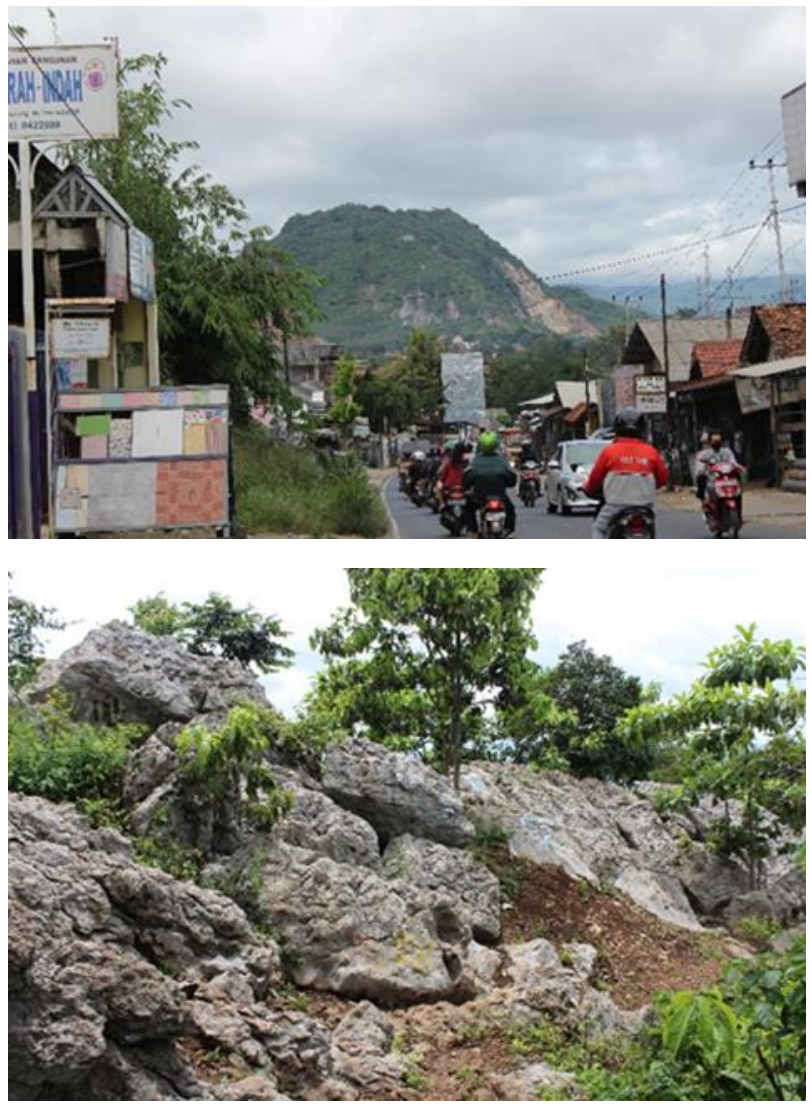

Fig. 2. Mt. Ciampea from below, the road between IPB University Dramaga and Mt. Ciampea (above). Sampling location at Lalana peak of Mt. Ciampea (below)

\section{Results and Discussion}

\subsection{Species Diversity}

In total, 1702 specimens belonging to 34 species from 16 families were collected at eight plots at Mt. Ciampea (Table 1). Stomacosmethis jagori (Cyclophoridae) was the dominant species comprising $24 \%$ of the individuals. Seven species were represented in our collection only by single specimens. Four of the recorded species were introduced species. Thirteen of the recorded species were not known from Mt. Ciampea so far. On the other hand, we could not recover 16 of the species recorded in previous surveys [12-14].

Empirical similarity indices (0.44-0.61) indicated strong differences between the species lists recorded in Mt. Ciampea during recent and historical (90 years ago) surveys (Table 2). However, the estimated similarity scores were much higher (0.81-1.00).

\subsection{Discussion}

Considering the 34 species found in our recent survey of Mt. Ciampea and the 38 species previously listed from that limestone outcrop [12-14], 50 of the 242 land snail species occurring on Java [16,21-22] are now known from that mountain (Table 1). Thus, $21 \%$ of the land snail fauna of Java were recorded from Mt. Ciampea, although it covers only $0.3 \%$ of the area of Java $\left(4 \mathrm{~km}^{2}\right.$ of 
$126700 \mathrm{~km}^{2}$ ). This underscores the importance of Mt. Ciampea for the conservation of land snail diversity in Java.

Although limestone outcrops cover only $4 \%$ of Java, $54 \%$ (139) of the land snail species occurring on Java were recorded in these areas [22]. Land snail species abundance is also higher in limestone areas. 1702 specimens were found in eight plots during our survey on Mt. Ciampea, 1123 specimens in 20 plots in Sukolilo [23] and 2919 specimens in 40 plots in South Malang [24]. In contrast, only 399 specimens were recorded in 24 plots on volcanic bedrock in Halimun Salak National Park (Nurinsiyah et al. in prep). The higher abundance in the limestone areas is undoubtedly due to the importance of calcium carbonate for land snails (see introduction).

Thirteen of the species recorded in our survey were not listed in the literature from Mt. Ciampea [12-14]. Most of these new records were smaller species that were probably overlooked in previous surveys. However, Lissachatina fulica and Bradybaena similaris are large, invasive species that colonized Mt. Ciampea only after the survey by van Benthem Jutting in 1930/1931. The invasive alien species are mainly inhabiting disturbed areas. Forest conversion to plantation/agriculture, massive quarrying, which reduced canopy coverage, and the increase of general human disturbance resulted in an increase of invasive species [24]. It is unlikely that the introduction of invasive species is the cause for the possible decrease of endemic species in Mt. Ciampea. Rather, both events might be the parallel results of habitat destruction. Sixteen species which were reported in the literature from Mt. Ciampea have not been found during our survey (Table 1). Among these species is Opisthostoma uranoscopium, which was originally described from Mt. Ciampea by van Benthem Jutting [10]. However, given that we have sampled at only 8 plots, we cannot exclude that some of these species are still living on Mt. Ciampea.

Actually, the high estimated similarity scores between our recent and previous surveys (Table 2) indicated that more sampling is necessary to ascertain the presence or absence of previously recorded species on Mt. Ciampea. This is urgently needed for planning conservation measures for rare and potentially endangered species considering that quarrying activities continue in the area. Reforestation, a stop in forest conversion and limiting quarrying spatially, are pivotal for a successful conservation of Mt. Ciampea's biodiversity.

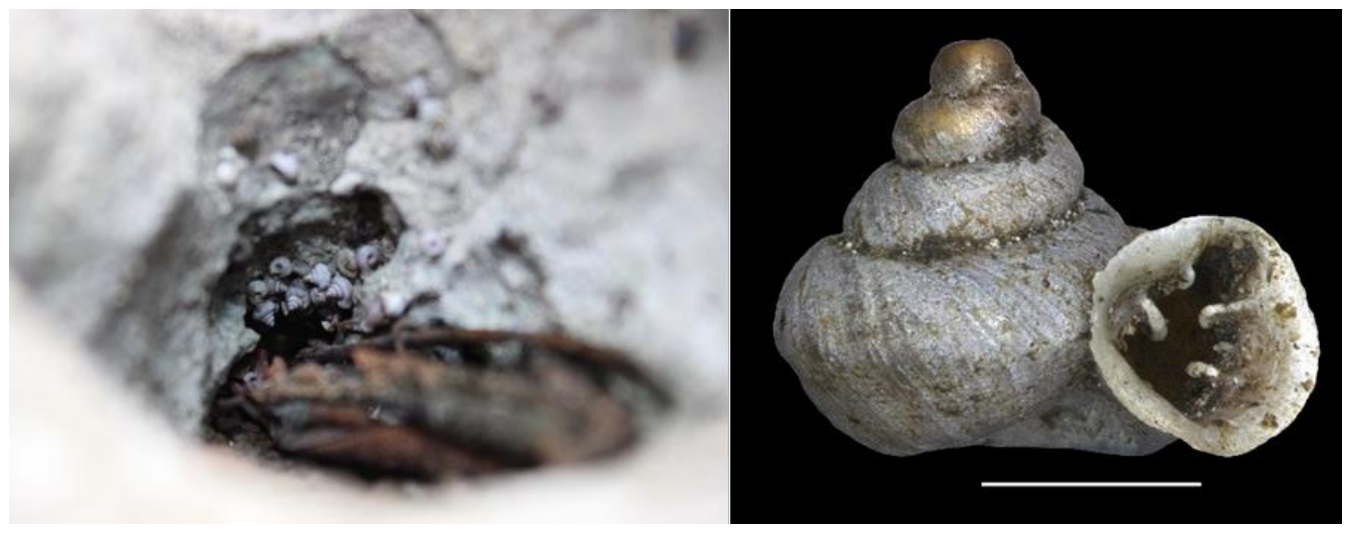

Fig. 3. Gyliotrachela fruhstorferi, a Javan endemic, from Mt. Ciampea (scale bar: 0.5mm)

Table 1. Land snail species and specimens recorded in Mt. Ciampea in a recent survey $(2013,2014)$ and by van Benthem Jutting [12-14]

\begin{tabular}{|c|c|c|c|c|c|c|c|c|c|c|}
\hline \multirow{2}{*}{ Family } & \multirow{2}{*}{ Species } & \multicolumn{8}{|c|}{ PLOTS } & \multirow[t]{2}{*}{ Literature } \\
\hline & & 1 & 2 & 3 & 4 & 5 & 6 & 7 & 8 & \\
\hline Hydrocenidae & Georissa javana Möllendorff, 1897 & - & - & 3 & - & 4 & 3 & 1 & - & + \\
\hline Cyclophoridae & Chamalycaeus crenilabris (Möllendorff, 1897) & 1 & 28 & 1 & 5 & 1 & 1 & - & - & + \\
\hline Cyclophoridae & Chamalycaeus fruhstorferi (Möllendorff, 1897) & - & - & - & - & - & - & - & - & + \\
\hline Cyclophoridae & Stomacosmethis jagori (Martens, 1860) & - & 55 & 162 & 71 & 104 & 13 & - & - & + \\
\hline Cyclophoridae & Cyclophorus perdix (Broderip \& Sowerby, 1830) & - & - & - & - & - & - & - & - & + \\
\hline Cyclophoridae & Cyclophorus rafflesi (Broderip \& Sowerby, 1830) & - & - & 1 & - & - & - & - & - & - \\
\hline Cyclophoridae & Japonia ciliocinctum (Martens, 1865) & - & 6 & 6 & 29 & 6 & 5 & 1 & 2 & + \\
\hline Cyclophoridae & Japonia grandipilum (Boettger, 1891) & - & - & - & - & - & - & - & - & + \\
\hline Cyclophoridae & Japonia obliquistriata Bullen, 1904 & 1 & - & - & - & - & - & - & - & + \\
\hline Cyclophoridae & Opisthoporus corniculum (Mousson, 1849) & - & - & - & - & - & - & - & - & + \\
\hline Diplommatinidae & Diplommatina auriculata Möllendorff, 1897 & - & - & - & - & - & - & - & - & + \\
\hline Diplommatinidae & Diplommatina baliana Fulton, 1899 & 9 & 4 & 71 & 25 & 71 & 6 & 17 & - & + \\
\hline Diplommatinidae & Diplommatina nevilli $(\text { Crosse, } 1879)^{1}$ & - & - & - & - & - & - & - & - & + \\
\hline Diplommatinidae & Opisthostoma javanicum van Benthem Jutting, 1932 & - & - & 1 & - & - & - & - & - & + \\
\hline Diplommatinidae & Opisthostoma uranoscopium van Benthem Jutting, 1932* & - & - & - & - & - & - & - & - & + \\
\hline
\end{tabular}




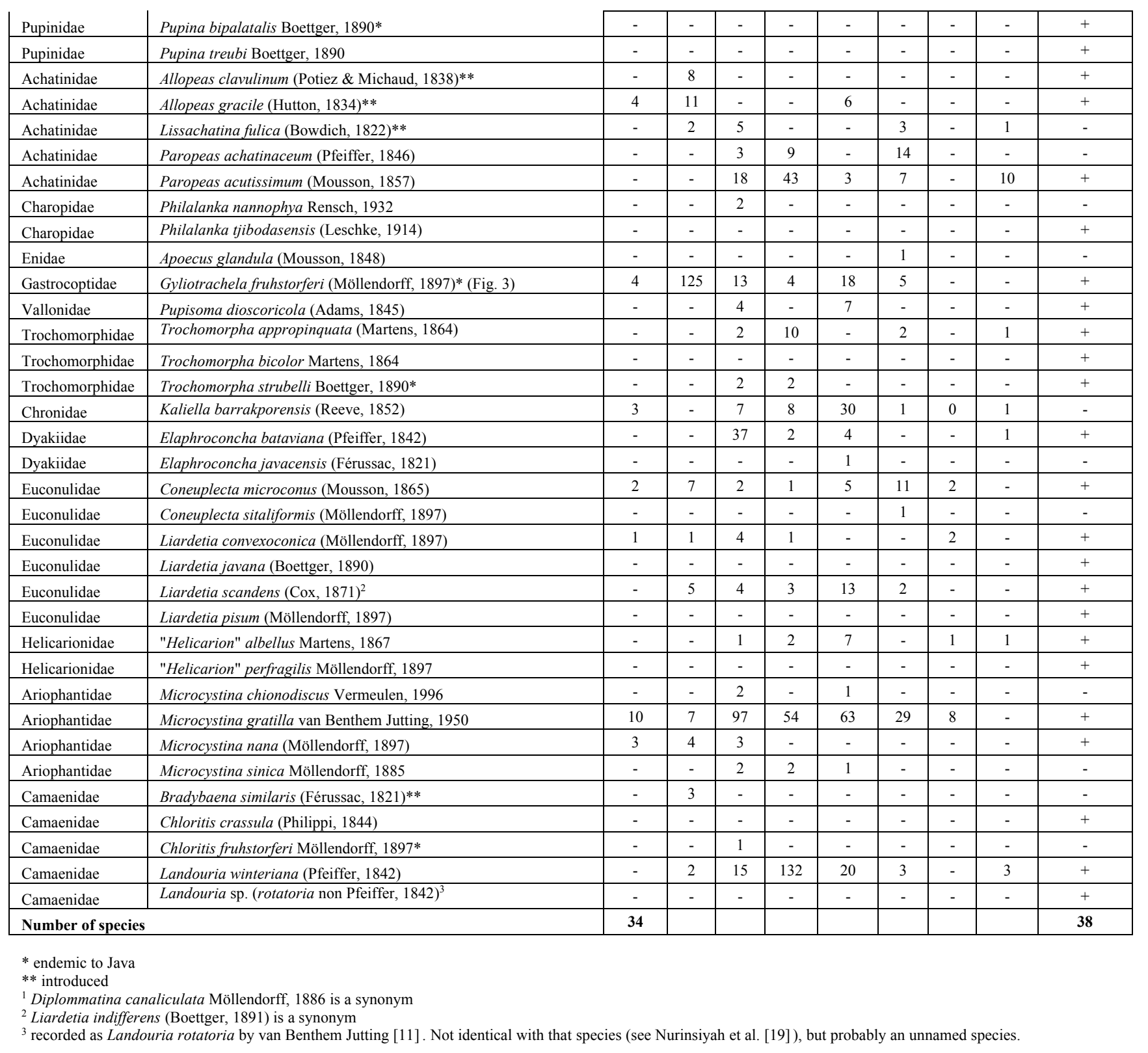

Table 2. Similarity scores between past and present records from Mt. Ciampea calculated with SpadeR.

\begin{tabular}{|c|c|c|}
\hline Index & Empirical & Estimated \\
\hline Jaccard & 0.44 & 0.81 \\
\hline ChaoJaccard & 0.44 & 1.00 \\
\hline Bray-Curtis & 0.61 & 0.81 \\
\hline
\end{tabular}

\section{Conclusion}

Our land snail survey in Mt. Ciampea showed that the species composition is different from that recorded about 90 years ago. However, a more extensive survey considering also areas not covered in our study is necessary to complete the list of currently occurring species and to map their occurrences on Mt. Ciampea as basis for conservation planning.
We are grateful to the staff of the Laboratory of Molluscs in the Research Centre for Biology for their help, T. Setiadi for the map, Lawalata (IPB University) for the assistance in the field, and $\mathrm{T}$. von Rintelen for critically reading a previous version of the manuscript. The research is supported by the IndonesiaGerman Scholarship Program/IGSP (Dikti-DAAD) and University of Hamburg, Germany. We also thank the committee of the International Symposium on Indonesian Fauna who supports the publication.

\section{References}

1. D. Balázs, Karszt-es Barlangkutatas, 5, 3-61 (1968)

2. R. Clements, N.S. Sodhi, M. Schilthuizen, P.K.L. $\mathrm{Ng}$, BioScience, $56 \quad$ (9), 733-742 (2006). https://doi.org/10.1641/00063568(2006)56[733:LKOSAI] 2.0.CO;2

3. J. Graveland, R. van der Wal, J.H. van Balen, A.J. van Noordwijk, Nature, 368, 446-448 (1994) https://doi.org/10.1038/368446a0 
4. I. Wäreborn, Ecography, 15, 62-69. (1992) https://doi.org/10.1111/j.16000587.1992.tb00009.x

5. R. Clements, P.K.L. Ng, X.X. Lu, S. Ambu, M. Schilthuizen, C.J.A. Bradshaw, Biol. Conserv., 141, 2751-2764 (2008). doi:10.1016/j.biocon.2008.08.011

6. M. Schiltuizen, T.S. Liew, B. Elahan, I. LackmanAncrenaz, Conserv. Biol., 19, 949-954 (2005) https://doi.org/10.1111/j.1523-1739.2005.00209.x

7. A. Satyanti, Y.W.C. Kusuma, Biotropia, 17 (2), $115-12$

http://dx.doi.org/10.11598/btb.2010.17.2.81

8. M.R. Febriano, http://lawalataipb.or.id/index.php/2010/12/09/gunu ng-kapur-cibodas-a-part-of-karst-region-frombogor/. [accessed on 25 September 2019] (2010).

9. M. Leschke, Mitteilungen aus dem naturhistorischen Museum in Hamburg, 31, 205284, (1914).

10. W.S.S. van Benthem Jutting, J. Conchol., 19, 196210, pl. 7. (1932)

11. A.S. Nurinsiyah, B. Hausdorf, Zootaxa, 4312, 201245

http://dx.doi.org/10.11646/zootaxa.4312.2.1

12. W.S.S. van Benthem Jutting, Treubia, 19, 539-604 (1948).
13. W.S.S. van Benthem Jutting, Treubia, 20, 381-505 (1950).

14. W.S.S. van Benthem Jutting, Treubia, 21, 291-435 (1952).

15. K.G. Emberton, T.A. Pearce, R. Roger, Malacologia, 38 (1-2), 203-212 (1996).

16. R.A.D. Cameron, B.M. Pokryszko, J. Conchol., 38, 529-547. (2005).

17. M. Schilthuizen, Contrib. Zool., 80 (1), 1-15 (2011).

18. J.J. Vermeulen, Basteria 59, 149-16(1996).

19. A.S. Nurinsiyah, M.T. Neiber, B. Hausdorf, Eur. J. Taxon, $\quad \mathbf{5 2 6}, \quad 1-73$ https://doi.org/10.5852/ejt.2019.526

(2019)

20. A. Chao, K. H. Ma, T. C. Hsieh, C.H. Chiu, http://chao.stat.nthu.edu.tw/wordpress/software do wnload/ [accessed on 25 September 2019] (2015).

21. B. Hausdorf, Zool. J. Linn. Soc., 185, 66-76 (2019) https://doi.org/10.1093/zoolinnean/zly031

22. A.S. Nurinsiyah, Land snails of Java: a study on systematics, ecology and biogeography, (Universität Hamburg, Dissertation, Hamburg, 2018).

23. A.S. Nurinsiyah, American Conchologist, 43 (3), 30-32. (2015).

24. A.S. Nurinsiyah, H. Fauzia, C. Hennig, B. Hausdorf, Ecol. Indic., 70, 557-665, (2016). http://dx.doi.org/10.1016/j.ecolind.2016.05.013 